\title{
Nature conservation as a driver in wind energy scenarios
}

\author{
Philip Gauglitz ${ }^{1 *} \mathbb{D}$, Sven Schicketanz ${ }^{2}$ and Carsten Pape ${ }^{1}$
}

\begin{abstract}
Background: Germany has set ambitious goals for the reduction of greenhouse gases. The decarbonisation of the energy system has been in focus. An important means to achieve this is the increased utilisation of wind energy. The growth of wind power entails changes not only in the electrical system but also in the landscape and environment. Prospectively, scenarios will have to consider a wide range of aspects, not only economics and technology but also nature conservation and social affairs. The authors are participating in the research study "Szenarien für den Ausbau der erneuerbaren Energien aus Naturschutzsicht", funded by the Federal Agency for Nature Conservation, which examines the possibilities of integrating nature conservation into the development of scenarios.

Methods: For aspects of nature conservation to be taken into account in scenario development, a multi-stage methodology has been developed to assess the conflict risk of wind energy and nature conservation throughout Germany. To ensure comparability of the scenarios, all of them are based on the same general framework consisting of fixed excluded areas, the same method of detail allocation and the same overall expected energy output. The "nature conservation" driver is integrated in the form of a nationwide comparative assessment of risk levels. The mapping of spatially differentiated risk levels for wind energy has been achieved in a GIS-based and discursive process.

Results: The results show that nature conservation can be addressed properly in scenario-building. Here, the method of multi-criterion scenario-building itself, with its focus on including nature conservation as one of several drivers determining the spatial distribution of wind turbines, is a major result. The authors have developed specific scenarios that mainly address questions of landscape and nature conservation. Out of the four generic scenarios presented for the year 2035, two have nature conservation as their main driver, whereas the other two consider energy-economic drivers only. Examining these scenarios provides insight into the influence of each driver. For example, adding nature conservation as the main driver (highest priority) reduces the specific conflict risk by $26.1 \%$, while at the same time only a relatively small increase in wind turbines is required $(+12.5 \%$ in numbers, $+2.3 \%$ in installed power capacity).

Conclusion: The methods developed here provide a driver for allocating wind power plants to reduce conflicts in high-risk areas. Furthermore, using the same spatial distribution of risk levels makes it possible to subsequently rate the scenarios from a conservation perspective. The method developed here provides the means to analyse trade-offs between relevant drivers. The "nature conservation" scenarios show a relatively small additional demand for wind turbines but a greater amount of avoided conflict risk.
\end{abstract}

Keywords: Wind energy, Scenario-building, Nature conservation, Rating conflict risk, Spatial distribution, Spatial planning, Drivers, Energy consumption covered by wind energy

\footnotetext{
* Correspondence: philip.gauglitz@iee.fraunhofer.de

${ }^{1}$ Fraunhofer IEE, Königstor 59, 34119 Kassel, Germany

Full list of author information is available at the end of the article
}

(c) The Author(s). 2019 Open Access This article is distributed under the terms of the Creative Commons Attribution 4.0 International License (http://creativecommons.org/licenses/by/4.0/), which permits unrestricted use, distribution, and reproduction in any medium, provided you give appropriate credit to the original author(s) and the source, provide a link to the Creative Commons license, and indicate if changes were made. 


\section{Background}

The transition of the energy sector, also known as Energiewende, aims at today's foremost ecological goals. Among other activities like energy saving, changing to renewable energies is the most central aspect to fulfilling international climate goals. In Germany, the Energiewende is a goal broadly accepted by the public $[1,2]$. At the same time, it is not without consequences for nature conservation $[3,4]$.

This paper builds on the research study "Szenarien für den Ausbau der erneuerbaren Energien aus Naturschutzsicht", funded by the Federal Agency for Nature Conservation. It describes a method designed to better take into account the consequences for nature and landscape associated with the energy transition in decisionmaking on a strategic level. The conflicts associated with renewable energies in the context of the expansion of onshore wind energy are particularly striking. Not only is this the type of energy generation with the biggest contribution to the current production of renewable energies [5] but also with the largest potential for expansion (cf. scenario framework 2030 NEP [6]). At the same time, the expansion of onshore wind energy is in conflict with nature and landscape conservation concerns, especially compared to other renewable energies $[1,7]$.

The state of the art thus concerns the various subject areas, in particular comparative assessments of conflict risks in relation to nature conservation, scenario development and placement of wind turbines according to specific criteria, and also the combination of these two areas. In the following, existing work relevant to the context but also its delimitation with this paper will be mentioned.

Several authors have shown that certain legally protected environmental goods are particularly affected, most of all the ecosystems and habitats of avifauna and bats as well as the beauty, diversity, singularity and the recreational value of nature and landscape $[8,9]$. These findings have led to the growing importance of spatial planning and consideration of environmental and social impacts. Some research projects are concerned with the optimisation of wind farms and the visualisation of wind turbines and their effects on ecosystems and nature conservation [10]. However, those approaches must not be confused with broad-based scenario-building and the inclusion of nature conservation as a criterion. Still, wind energy scenarios usually consider economic and technical factors only.

The aim of the study was, therefore, to devise a method for assessing the risk that conflicts occur (conflict risk) and to integrate nature conservation into multi-criterion scenarios. While multi-criterion scenario-building is often used to evaluate the spatial distribution of renewable energy sectors, e.g. by WWF and Agora [11, 12], only a few studies on the national level have taken nature conservation into account, e.g. Federal Agency for Nature Conservation [13]. At the subnational level, more studies included nature conservation, if not as a legitimate driver, at least as an exclusion criterion [14, 15]. Proposals for the methodological inclusion of bird strike have been made by Drechsler et al. [16] but concern a rather narrow area of nature conservation. Lately, there have been calls for recognising ecological aspects beyond exclusion criteria in nationwide energy scenarios, e.g. Naegler [17]. At this point, we should mention a study on the national level on the topic of wind energy and nature conservation by Cowell [18]. However, it focuses on "efforts of the Welsh Assembly Government to develop a spatial planning framework for wind energy" and, with this focus on concrete project planning for wind farms planning for a specific area, is not transferable to a general scenario perspective.

In a broader sense, research on ideal distances between turbines in wind farms [19] and the optimisation of wind farm placement $[20,21]$ are also related to the subject of this paper. However, they are only concerned with the classification of a specific sub-step of the presented methodology, namely the selection of possible sites.

This study is necessary to fill gaps in the literature and current methodology. It can support policy advice to investigate possible levers from different spatial distributions of energy production to nature conservation aspects.

\section{Methods}

The overall approach is divided into the following methods and steps:

- Method for determining nature conservation as a driver

- Methods for determining other drivers

- Selection of scenario settings

- Placement algorithm for potential locations of wind turbines

- Technical methods for the development of scenarios and their evaluation

To establish nature conservation as a driver for spatial allocation in wind energy scenarios, a complex method was devised. It aims at a spatially differentiated assessment of nature and landscape conservation issues at the federal level. Here, the small scale only allows conflict risks to be addressed. The mapping of risk levels for wind energy was achieved in a combined geographic information system (GIS)-based and discursive process. At first, considering the typical effects of wind turbines, 
potential conflicts were identified-for example, with avifauna, bats or recreational functions of the environment $[22,23]$. Based on knowledge about possible conflicts, spatial information on sensitive areas was gathered. For example, datasets about Nature 2000 sites were suitable. Overall, there is limited homogenous data on the federal level. Available data include information about protected areas, land use, topography (elevation model, visibility model) and occurrence of species. Each of these datasets contains multiple categories, see Table 1. Protected areas, for example, include nature reserves, landscape conservation areas, biosphere reserves, Nature 2000 sites and others. These categories can be used to determine the spatial distribution of sensitive areas where conflicts may arise.

However, none of the geodata contains the precise information necessary to pinpoint specific conflicts. Therefore, an assessment of conflict risks with consideration to impact, vulnerability and the normative meaning of the information used, as well as the accuracy of the geodata, is necessary. Concerning these characteristics, the assessment is carried out by leading ecologists, environmental, conservation and spatial planning experts from the federal government, universities and consulting firms. The list of categories is presented to the group of experts in the form of a modified Delphi survey [33]. Within the development and testing of the method, the number of experts is limited to 15 . For the implementation, a nationwide participation of all experts is recommended. The respondents have an opportunity to assess each category in two rounds. From the second round onwards, feedback is given on how other experts have responded. The main objective is to differentiate between lower and higher conflict risks with nature and landscape conservation on a five-point scale for each category and protected good (fauna, flora, biodiversity, soil, water, air, landscape and recreation). The outcome of the Delphi survey in the first round showed that some categories were assessed unanimously while other categories were assessed differently. The differences mainly result from the specific views of the experts and could be eliminated in the second round by a consensus for

Table 1 List of datasets and included categories

\begin{tabular}{|c|c|}
\hline Dataset & Category \\
\hline $\begin{array}{l}\text { Protected areas } \\
\text { Source: Federal Agency for Nature } \\
\text { Conservation }[24,25]\end{array}$ & $\begin{array}{l}\text { - Nature reserves } \\
\text { - Landscape conservation areas } \\
\text { - Biosphere reserves (zone III) } \\
\text { - Ramsar areas and adjacent areas at a distance of 0-1000 m } \\
\text { - Nature } 2000 \text { sites: } \\
\text { o Special protection area with/without the occurrence of bird species } \\
\text { sensitive to wind energy } \\
\text { o Areas adjacent to special protection areas with occurrences of bird } \\
\text { species sensitive to wind energy at a distance of } 1000-2000 \text { m and } 2000-3000 \text { m } \\
\text { o FFH areas without occurrences of bird or bat species sensitive against wind energy } \\
\text { o Areas adjacent to FFH areas with occurrences of bird or bat species sensitive to } \\
\text { wind energy at a distance of 0-1000 m, } 1000-2000 \text { m and } 2000-3000 \text { m } \\
\text { - Areas adjacent to national parks at a distance of } 0-1000 \text { m } \\
\text { - Areas adjacent to nature conservation areas at a distance of 0-1000 m } \\
\text { - Areas for the biotope network of wetland, dry and forest habitats as well as habitat } \\
\text { networks with international significance } \\
\text { - Areas of the Grünes Band Deutschland }\end{array}$ \\
\hline $\begin{array}{l}\text { Important Bird Area } \\
\text { Source: NABU [26] }\end{array}$ & $\begin{array}{l}\text { - Important Bird Areas (IBA) of categories A1-3, A4 (iv), B1 (iv), B2, C1 and 2, C5 and } 6 \\
\text { outside Nature } 2000 \text { sites and adjacent areas at a distance of 0-1000 m }\end{array}$ \\
\hline $\begin{array}{l}\text { Water conservation } \\
\text { Source: Federal Institute of Hydrology } \\
(\mathrm{BfG})[27,28]\end{array}$ & $\begin{array}{l}\text { - Water conservation areas } \\
\text { - Medicinal-spring protection areas both already established and in planning }\end{array}$ \\
\hline $\begin{array}{l}\text { Land use } \\
\text { Source: Federal Agency for Cartography and } \\
\text { Geodesy (BKG) [29] and DDA [30] }\end{array}$ & $\begin{array}{l}\text { - Habitats of bird species of the Helgoländer Papier sensitive to wind energy with } \\
\text { mortality index A, B and C outside protected areas }\end{array}$ \\
\hline $\begin{array}{l}\text { Land use } \\
\text { Source: Federal Agency for Cartography and } \\
\text { Geodesy (BKG) ATKIS-AAA-Basis-DLM [29] }\end{array}$ & $\begin{array}{l}\text { - Deciduous, coniferous, mixed-forest and adjacent areas at a distance of 0-200 m } \\
\text { - Farmland } \\
\text { - Pastures/permanent grassland } \\
\text { - Open land outside agricultural land } \\
\text { - 250-m corridors along large water axes and adjacent areas at a distance of 250-1000 m }\end{array}$ \\
\hline Historic forest sites of Germany & - Historic forest sites and adjacent areas at a distance of 0-200 m \\
\hline
\end{tabular}


the federal level. To generate a federal nature conservation conflict risk rating, the partially overlapping geodata are aggregated within the GIS based on rules. The conflict risk for each cell of the grid $(25 \times 25 \mathrm{~m})$ associated with the protected good is first determined using the maximum-value principle per protected good. Later, the conflict risk concerning all protection goods is determined for each cell, also using the maximum-value principle, see step 3 in Fig. 1. For example, conflicts with bird presence are mapped by several different categories. Since the conflict indicated by all categories is the same, the highest conflict risk remains, which avoids double evaluations of categories that represent the same conflict. However, it should be taken into account that several different conflicts can occur in a single cell. If the overlapping categories represent various protected goods and, therefore, different potential conflicts, the conflict risk will increase due to an increased probability of occurrence, see step 4 in Fig. 1. Thus, in addition to the maximum conflict risk value, the model also calculates the density of conflicts. For the overlapping risk value, the original value of the cell is increased by one based on rules if it has a high conflict risk class $(\mathrm{CRC}>3)$ and more than three different protected goods are affected. This should also be done if a cell with the highest conflict risk class to date has a higher conflict risk according to the extended aggregation rule. Therefore, the additional conflict risk class with the value "overlapping high conflict risk" is introduced in the result of the evaluation. In total, there are six CRCs. The result is a map that can be used as a driver to allocate wind power plants in such a way as to reduce conflicts in high-risk areas, see Fig. 1.

In addition to nature conservation, two other drivers are used for scenario development. "Wind resources" is used as the basic driver for all scenarios. The calculation is based on mesoscale models for wind speed. In multicriterion scenarios, a comparison of possible electricity yields is useful for achieving a correct evaluation of the advantages and disadvantages of the locations despite the high non-linearity of the wind energy amounts in relation to wind speed. An existing wind energy yield model from Fraunhofer IEE is used to generate the wind power produced in 1 year. The method is described in Arbach et al. [34]. Model development has made strides, particularly in the area of underlying weather models and calibration factors: the numerical weather prediction model Cosmo-DE [35] has been used here. The second driver, "energy consumption ratio", i.e. the share of the power consumed that is wind generated, has been specifically developed for the purpose of this study. Just like wind suitability, the driver "energy consumption ratio" should reflect the view of energy economics, in contrast to the criterion addressing nature conservation discussed later. This driver is concerned with the question of how much energy can be generated in the location where it is

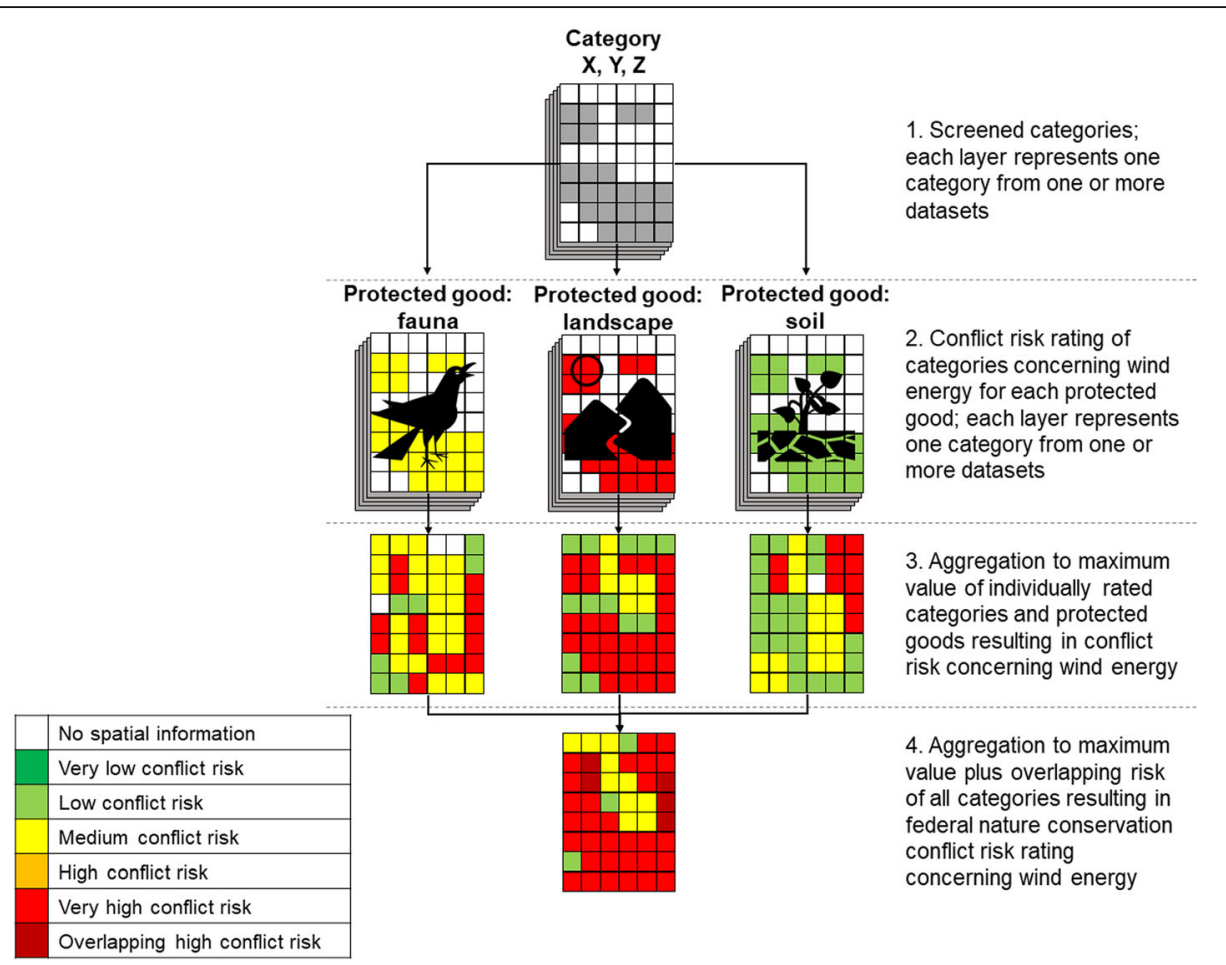

Fig. 1 Conflict risk rating in protected goods 
also consumed. One input variable is local electrical load, the other installed wind power, which is determined in the allocation process. The methodology for determining area-related load in municipalities is an output of an existing Fraunhofer model and is described in Härtel et al. [36]. The existing model uses top-down energy consumption (at different levels) and bottom-up distribution variables to model loads at hectare resolution. In the context of the research described here, the load is assumed to be area wide over communities. The temporal resolution is not taken into account, i.e. the energy quantity is compared, but not the temporal simultaneity values of the energy generation load. Considering that no grid calculations have been carried out within the framework of the project, the assessment of the "consumption" scenarios can only be understood as an indicator for the subject at hand. The driver is deliberately formed independently of the electricity grid's actual supply areas. In contrast to wind suitability, "energy consumption ratio" is not a value that is independent of the expansion in the scenarios but a quantity that is determined iteratively. During the site-selection process, the ratio of the wind power generated and the local consumption within the surrounding area (diameter of 50 $\mathrm{km}$ ) is checked after each site selection. If production exceeds $75 \%$ of consumption (which includes the industrial consumptions), locations in the vicinity will receive a malus. The limits for the increase of the malus are not defined from a technical point of view. They are the result of discussions in the project team to adequately reflect the influence of the load. Nevertheless, they are to be regarded as estimated values and are, therefore, integrated into the model as variable input variables. In contrast to the other drivers, "energy consumption ratio" is, therefore, not a value that can be assigned to each location from the outset but a value that results from the iterative allocation process and changes with each wind turbine placed. Figure 2 shows the devaluation factor used in the project for different shares of energy consumption covered by wind energy.

The course of the function was worked out by the project team. For the analysis of the robustness, the function course was varied in a sensitivity analysis. On the one hand, a stronger devaluation was made on the basis of an earlier and stronger reduction. On the other hand, a weaker devaluation was achieved by a later starting and slower reduction. As expected, a stronger devaluation factor leads to a stronger redistribution compared to the "efficiency" scenario and thus a higher number of installations and vice versa. However, the changes are relatively small, the change in the number of installations varies only $+2.9 \%$ (to 21,880 ) and $-1.9 \%$ (to 20 , 850). Here, the framework numbers at the federal state level and the general methodology of the devaluation factor appear to have a stronger influence than the very precise functional course, which can, therefore, be regarded as relatively robust.

Within the wide range of possibilities for scenariobuilding, the authors decided to simulate generic scenarios describing the influences of different drivers on

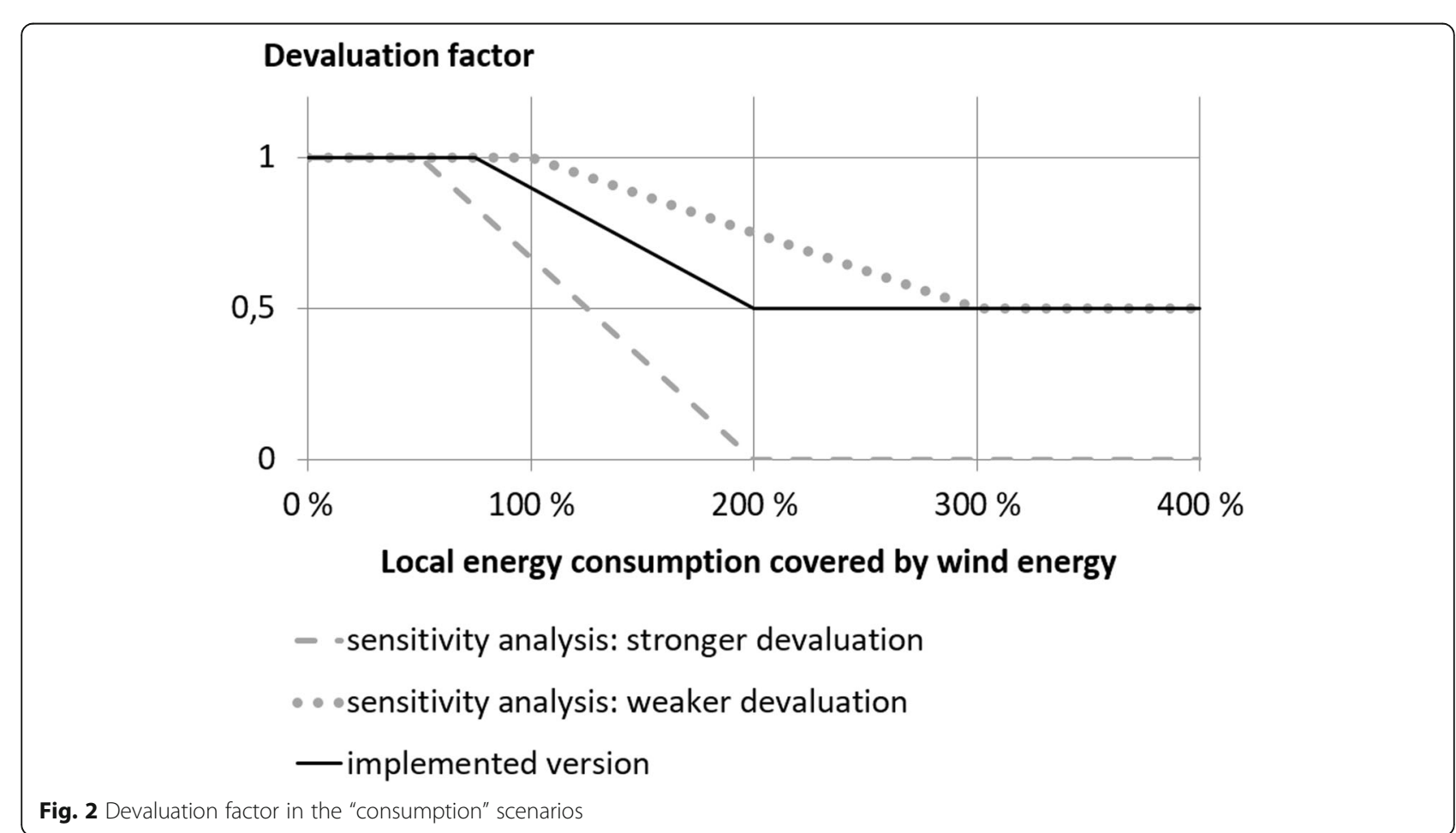


allocation patterns. Considering existing wind turbines or annual repowering would not help but, on the contrary, complicate scenario evaluation. In consequence, plant distributions are based on a greenfield approach with a fixed target energy quantity. The basis for the distribution is the total area of Germany minus the preexcluded areas. All legally inadmissible sites, e.g. in national parks, are initially excluded in advance. Furthermore, all sites that are predominantly excluded by law in individual cases, e.g. within a distance of less than 1000 $\mathrm{m}$ from residential buildings, as well as sites that are unsuitable from a technical point of view, e.g. steep areas (gradient over 30\%).

The resulting scenarios are well suited to identify the influences of several drivers but must not be mistaken for scenarios that likely represent the future accurately. Wind suitability serves as the basic criterion, and "wind power" is the only driver in the first scenario. The other scenarios include every combination of the other two drivers ("energy consumption ratio" and "nature conservation"). Figure 3 shows an overview of the drivers.

The allocation process has two steps and uses a specific placement algorithm. In the first step, the grid cells are scanned and the next free cell is identified. In the second step, the possible location is marked and an elliptical buffer zone is drawn. This ellipse describes the necessary distance from the closest wind turbine, defining all pixels contained as occupied. The minimum distance between turbines depends on the main wind direction. It is commonly assumed that, in the main wind direction, a distance of five times the rotor diameter must be maintained. In the secondary wind direction, three times is sufficient [37, 38] (see Fig. 4). The assumed rotor diameter is $135 \mathrm{~m}$. It should be mentioned that although rotor diameter is fixed regardless of location, sitespecific requirements are taken into account by selecting three types of turbines. They differ in hub height $(160$ $\mathrm{m}, 135 \mathrm{~m}, 110 \mathrm{~m})$, power density $\left(220 \mathrm{~W} / \mathrm{m}^{2}, 285 \mathrm{~W} / \mathrm{m}^{2}\right.$, $\left.350 \mathrm{~W} / \mathrm{m}^{2}\right)$ and the resulting rated power $(3.15 \mathrm{MW}$, 4.08 MW, 5.01 MW). The three types represent a realistic plant mix for the year 2035, according to analyses of previous plant development [39]. While in reality a different rotor diameter seems realistic for these different turbine types, a uniform diameter is useful for the modelling since a continuous placement algorithm (most resource-intensive part of the model) can be used, and at the same time a changed rotor diameter does not represent a generally changed land consumption since all three variables (apart from form factor influences) are generally linearly related: energy quantity/rotor area/area consumption. Therefore, a uniform rotor diameter seems appropriate and at the same time acceptable as an assumption. However, the three turbine types have not been chosen to reject the diversity of turbine types used in reality but to provide a good basis for comparability in the context of the greenfield approach described above.

Thus, a good utilisation of the potential areas calculated in the scenarios is achieved using the described algorithm (see Fig. 4).

The best locations are used for scenario-building, with the evaluation depending on the combination of drivers in each scenario. For scenarios that do not take consumption into account, the evaluation for each location is unique. Considering the share of load covered by wind energy turns the allocation process into an iterative process as described above.

\section{Results}

The following two results best describe the main research findings:

- Nationwide "nature conservation" conflict risk map

- Methodology and numerical examples for multicriterion scenarios
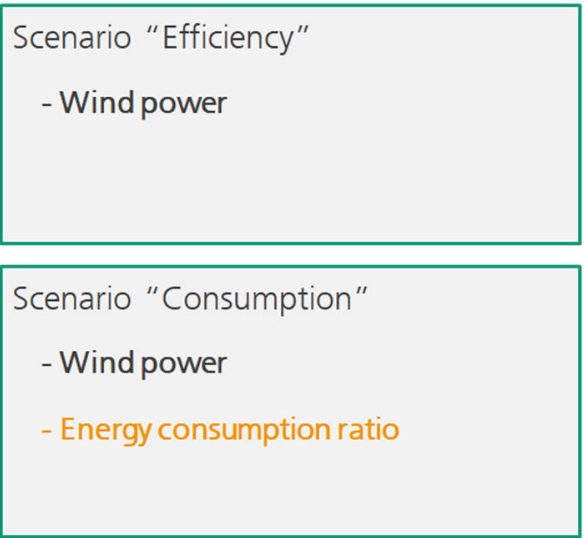

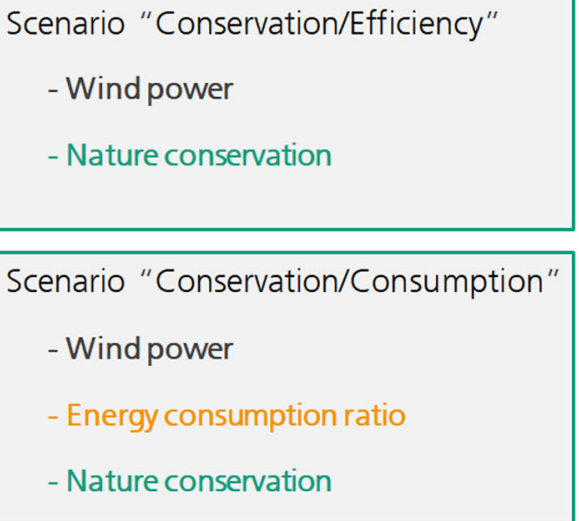

Fig. 3 Different drivers in the four scenarios 


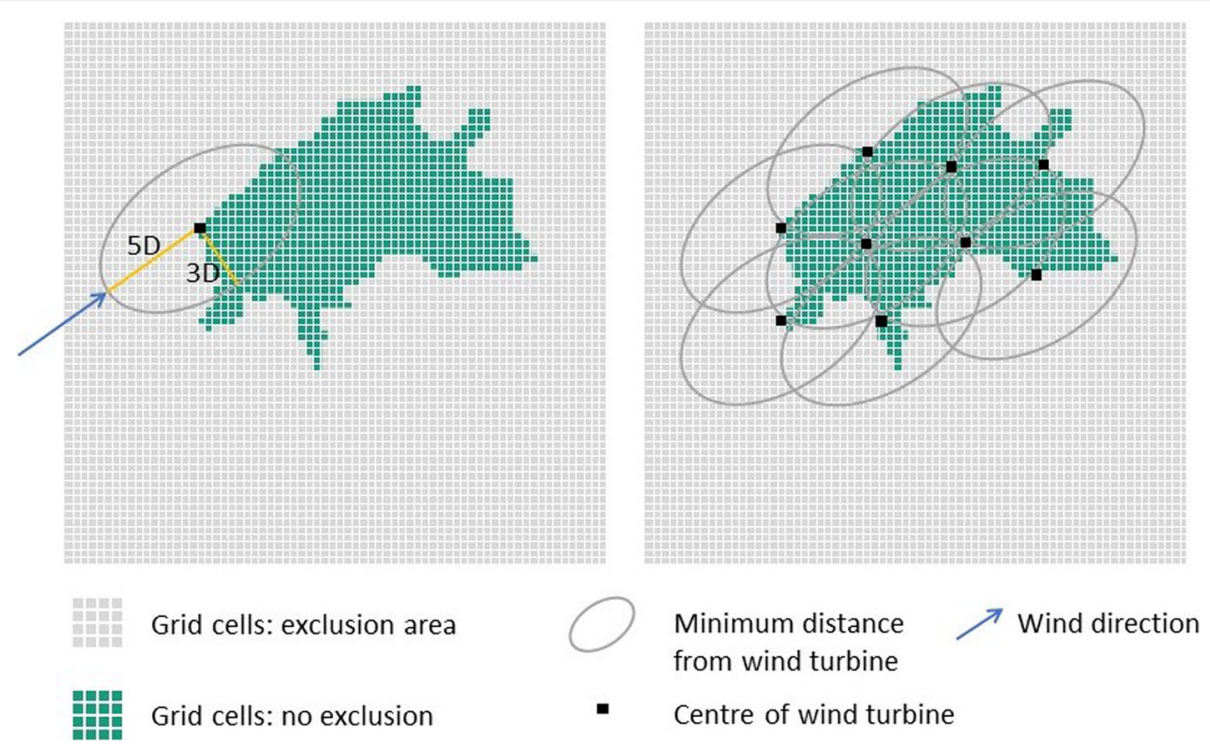

Fig. 4 Schematic placement of wind turbines

A major result is the nationwide mapping of nature vulnerability against wind energy. Further insight into how the map was generated is provided in "Methods". It is based on available data, e.g. Nature 2000 sites and information about habitat and species protection. Overall, the model considers all concerns of nature conservation such as flora and fauna, biodiversity, water, soil, air and climate as well as landscape and recreation. Risk levels on a six-point scale describe the compatibility of nature conservation and wind energy. A low level indicates an area where sustainable usage is predominantly possible, and a high level an unsustainable area. The risk level is the result of a comparative assessment. The numerical output of the methodology developed here is a gridshaped and high-resolution assessment of vulnerability in terms of nature conservation. With this highresolution map, conventional wind energy scenarios can be evaluated from a nature conservation perspective. The evaluation unit of total conflict risk is physically undefined and results from the sum of claimed conflict risk levels. At the same time, the conflict risk rating can also be used-this is the second important result of the study-as a key driver in multi-criterion scenariobuilding. Both options, the assessment of existing scenarios and the implementation of nature conservation as an input for scenario-building, are schematically presented in Fig. 5.

The other major results are four multi-criterion scenarios which demonstrate the influence of nature conservation aspects on the potential spatial distribution of wind turbines. In addition to the analyses of impacts on nature conservation, the scenarios are also evaluated with consideration to energy management issues. The generic scenarios are not meant as a future prognosis but to describe the influences of several drivers. For this reason, existing wind turbines and annual repowering were deliberately disregarded. The scenarios are based on a greenfield approach for a fixed target energy quantity. Each placement of a wind turbine depends on the respective driver combination in each scenario. While all scenarios contain a driver regarding the wind conditions, the "consumption" and "nature conservation" drivers are combined differently in each scenario.

All four scenarios have the same amount of produced wind energy (269 TWh per year). The amount of wind energy results from an analogous consideration of wind energy rated power as in [12], which was supplemented by more recent figures from updated sources of grid development plans [6]. This rated power results-for the specific turbine distribution from the "Efficiency" scenario-in an energy quantity that is also used as a target value for all other scenarios. These differ in the number of installed wind turbines, their spatial distribution and the total conflict risk (without physical unit, see above for derivation). The results of the four scenarios are shown below. The "energy consumption ratio" driver has the greatest influence on spatial distribution, cf. Fig. 6 . However, the influence of the "nature conservation" driver on the distribution must not be neglected. The comparison of the scenarios "Efficiency" and "Conservation/Efficiency" shows that only a small increase in the number of wind turbines placed $(+12.5 \%$ in numbers, $+2.3 \%$ in installed power capacity) is needed to generate the same amount of energy, while a strong reduction in total conflict risk is achieved (-26.4\%). Figure 7 shows the relative (plant-related) conflict risk and the total 


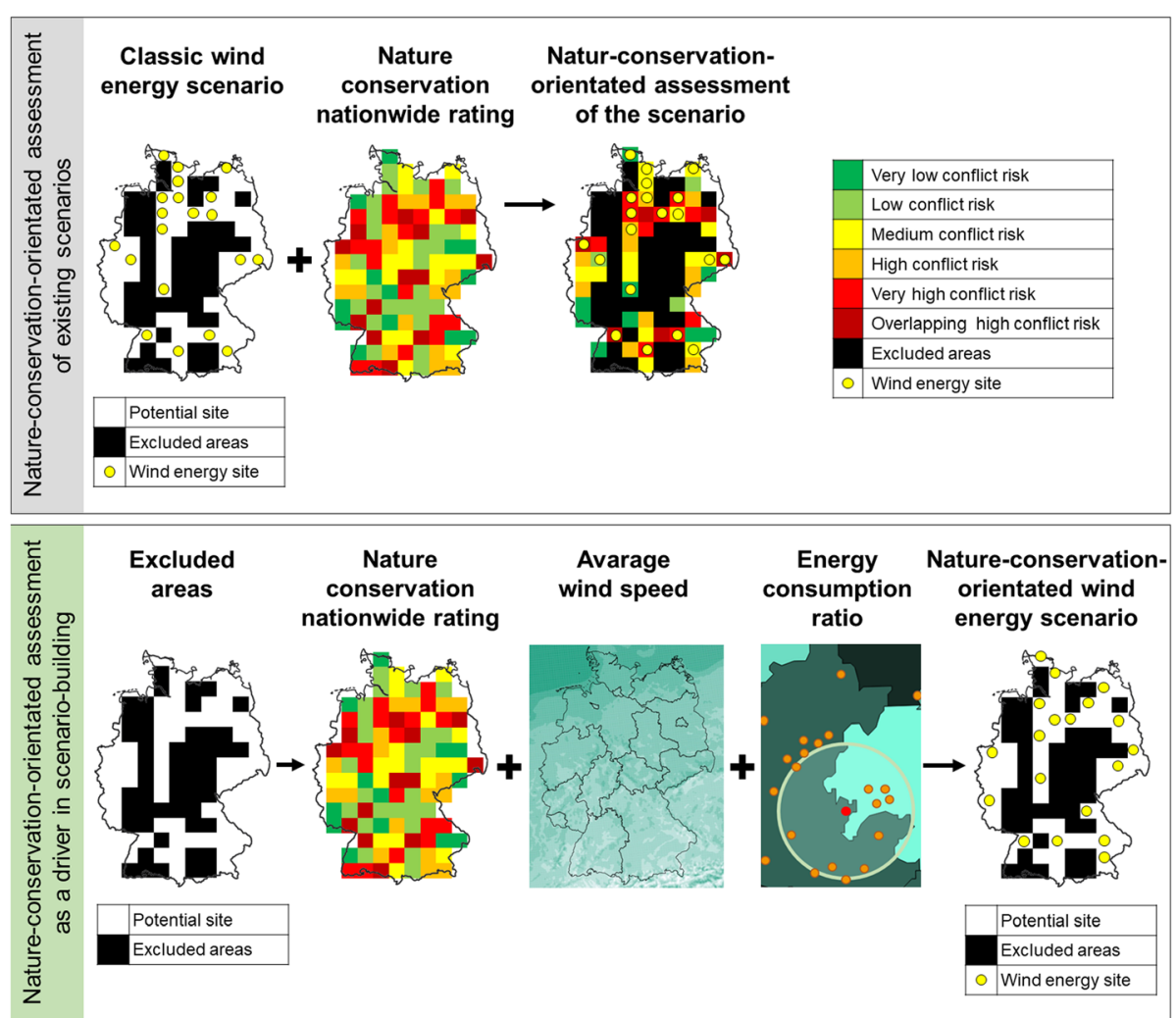

Fig. 5 Possible applications of the conflict risk rating in scenario assessment and development

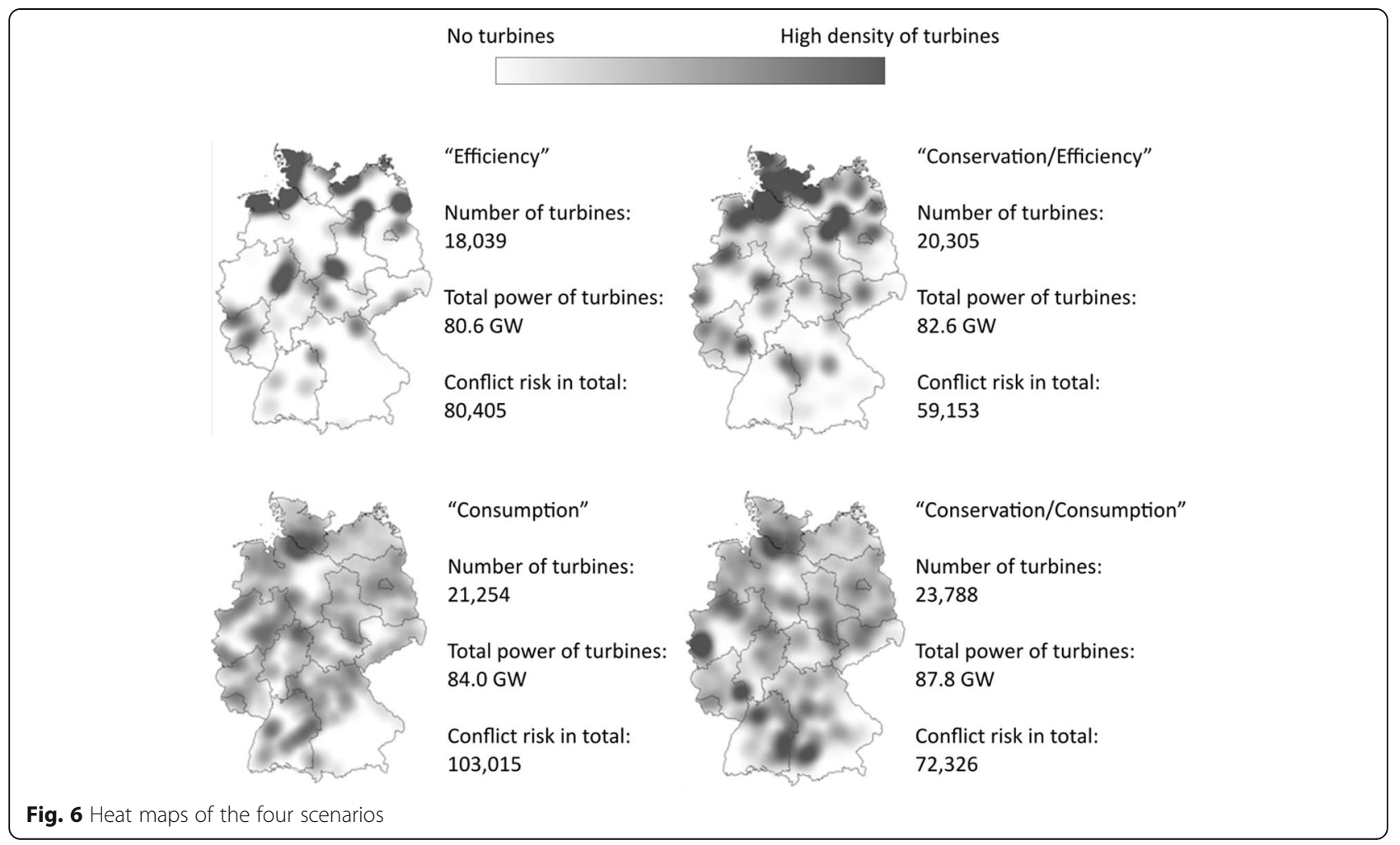




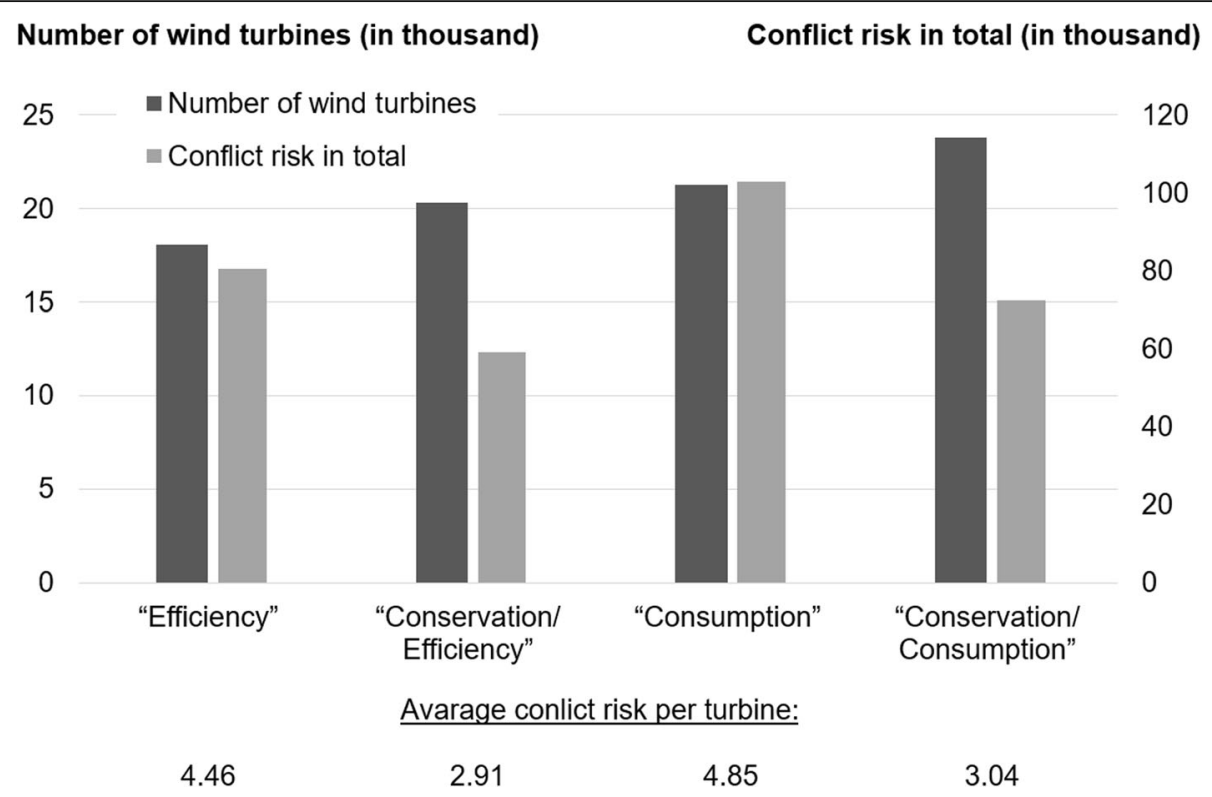

Fig. 7 Total wind turbines, conflict risk in total and average per wind turbine

conflict risk for each scenario with respect to the total number of wind turbines used. It becomes clear that the low plant-related conflict risk of the "Conservation" scenarios significantly reduces the overall conflict risk despite the greater amount of investments (see Figs. 6 and 7). As for the methodology, these results show that the acquired driver "nature conservation" is very well suited to adequately take into account nature and landscape concerns in the scenarios.

The influence of the drivers on the spatial distribution of wind turbines is mostly contrary. The highest degree of efficiency is achieved through the central allocation of wind turbines in windy regions. In contrast, an expansion close to where the energy is consumed requires a decentralised distribution, with few exceptions. At the same time, particularly windy regions are often prone to conflict from a nature conservation point of view. In conclusion, targets in one area can only be achieved at the expense of other targets. The methodology presented can be used to illustrate these effects and to support decision-making with respect to the necessity of weighing and balancing contradictory goals.

\section{Discussion}

The described research shows how nature conservation conflict risk can be mapped nationwide and used as a driver for scenario-building. Naturally, under the assumption that the same amount of energy is generated, the addition of drivers leads to an increased turbine requirement. An interesting finding is that the results of the "nature conservation" scenarios show a relatively small additional demand for wind turbines but a greater amount of avoided conflict risk, as seen in the results, e.g. Fig. 7.

To evaluate these results, it is essential to fully comprehend what is behind the multi-stage procedure of assessing nature conservation. The strength of the procedure- $\mathrm{a}$ broad database and comprehensive involvement of experts in assessing different categories-has also proved to be a hurdle: over the course of the research work, the inclusion of a great number of expert opinions proved difficult on several occasions. This was mainly due to three major issues: the necessity to comprehensively clarify (1) the used terminology, (2) the complexity of the multi-stage assessment procedure and (3) the required data quality. While it is rather easy to provide a glossary defining all terms in need of clarification, it became apparent that a longer period of time is required for experts to get accustomed to the assessment procedure and to apply coherent benchmarks. Concerning the use of nationwide data, it was challenging to convey the utilisation of general area information (e.g. Nature 2000 sites) to address a certain conflict (e.g. disturbance or collision of birds). Experts proposed to consider regional data, which possess a greater level of detail (e.g. detailed mapping of bird occurrences in a region). Although there is a justified interest in using more precise data, a nationwide comparable assessment first of all requires homogeneous data. Nonetheless, it became obvious that the existing federal data leave room for improvement.

Eichhorn et al. [40] also come to this conclusion-also for the level of the federal states [41]. They limit the consideration of nature conservation concerns to certain 
protected areas in which species sensitive to wind energy are protected. The spatial differentiation of the scenarios is less pronounced than the approach presented. In contrast to the intended simple determination of scenarios for the expansion of wind energy according to Eichhorn et al. [40], particular importance is attached here to the consideration of all nature conservation concerns. Especially possible conflicts outside the relevant protected areas (SPA and FFH) are taken into account to get a step closer to reality.

In fact, here are numerous other projects concerned with the building of wind energy expansion scenarios based on placement algorithms and location evaluations or weightings, such as Braun et al. [42] and Jetter et al. [43], to name two important study reports for Germany. In some scientific papers, some highly detailed criteria were included to arrive at GIS-supported wind energy distributions $[44,45]$. Similar to some of the studies mentioned above, this study uses an algorithm with elliptical minimum-distance areas around the wind turbines and includes a subsequent selection of potential locations. In contrast to most of the other studies, where site selection is mainly based on an energy-economic evaluation, this paper focusses on nature conservation as a driver. It should not be forgotten that the numerical results have been compiled in generic scenarios in which wind turbines are distributed over available areas until an annual power generation quantity is reached without taking into account the number of existing turbines or simulating an annual extension. They should, therefore, not be mistaken for scenarios that likely represent the future accurately. Nevertheless, our findings offer opportunities to support policy advice decisively and close a gap in scenario-building.

The adaptable structure of multi-criterion scenariobuilding also allows for supplementary future research work. While various complementary research activities are conceivable, the consideration and quantification of the required network expansion for the various scenarios are particularly important. As numerous network development studies of the grid extension conduct a cost assessment only, a consideration of conflict risks concerning nature conservation would be extremely helpful. First of all, a possible scenario would have to include a similar assessment of nature conservation conflict risks concerning grid extension. Furthermore, a reasonable consequence would be to add comprehensive overall energy simulation (which includes all energy producers and consumers connected to the grid) and grid calculation, which, taken together, would result in more realistic scenarios. This would particularly improve the evaluation of the "consumption" scenarios. A first intermediate step could be the implementation and consideration of a current consideration of the actual momentary correspondence between load and wind energy generation, whereby it can be questioned whether this-as long as a grid calculation does not take place-actually represents a qualitative added value compared to the currently used methodology with annual energy consumption. In combination with existing methods of network calculation, the method presented here constitutes a suitable building block for this. However, a more holistic methodology encompassing all elements yet needs to be developed.

\section{Conclusion}

This study aimed to implement nature conservation as a valid driver in scenario-building. For this purpose, adaptable methods for a nationwide rating of nature conservation conflict risk and modelling of multi-criterion scenarios with high-resolution site selection were developed. It turned out that a suitable driver could be found that could easily be integrated into the multi-criterion scenario-building method. As far as the necessity of such a driver is concerned, it could be shown, based on the generic scenarios, that nature conservation has a significant impact on scenario results. Furthermore, it became clear that prioritising any of the three drivers would lead to significantly deteriorated achievement of objectives in the other areas. This negative correlation between the main drivers "efficiency", "consumption" and "nature conservation" makes it particularly important to consider them equally. It must be concluded that a planning process that takes all drivers into account is to be recommended. Last but not least, this requirement also leads to the necessity of weighting the drivers. The discussion showed that these issues must be resolved in political and social debates concerning the future expansion of wind energy. The subject is of increasing importance against the background of the declining number of new wind turbines being built. The expansion of wind energy fell by about 50\% in 2018 compared to 2017. Surely, this is not in the spirit of the Energiewende. In conclusion, it can be stated that the presented methodology can greatly contribute to answering the question of how and where an expansion of onshore wind energy should proceed.

\footnotetext{
Abbreviations

NEP: Netzentwicklungsplan Strom (network development plan); GIS: Geographic information system; CRC: Conflict risk class

\section{Acknowledgements \\ The authors are grateful to Pascal Kinast for his expertise and professional opinion.}

\section{Authors' contributions}

The methodology of nature conservation assessment and the derivation of a uniform "nature conservation" driver have been developed and described by SchS. PG has developed and described the methodology of multi-criterion scenarios in general, the consideration of individual criteria in particular and the selection of sites. CP has developed the geometric investigation of potential wind turbine sites. The methodological approach for considering
} 
local energy consumption covered by wind energy as a driver has been developed by CP and PG. The presentation preceding the paper on the same topic at the UFZ Energy Days was given by PG. SchS and PG have contributed equally to the writing, and an additional revision of the manuscript has been provided by CP. All authors read and approved the final manuscript.

\section{Authors' information}

About the authors

Philip Gauglitz studied mechanical engineering at the RWTH Aachen University, majoring in energy technology. As a project manager and research associate at Fraunhofer IEE, he works on and leads research projects in the field of regionalisation of energy producers (e.g. wind turbines) and energy consumers (e.g. electric vehicles) in scenarios.

Sven Schicketanz studied environmental planning at the Technical University of Berlin, graduating as Diplom-Ingenieur. At Bosch \& Partner GmbH, he works as a project manager in the field of environmental impact assessment, focusing on the compatibility of renewable energies with nature conservation. Dr Carsten Pape studied biology at the University of Göttingen and received his doctorate at the University of Hamburg, followed by a master's degree in renewable energies and energy efficiency at the University of Kassel. As head of the group Scenarios and System Modeling, he researches the mapping of future energy supply systems.

\section{Funding}

The methodological considerations and scenarios included herein have been developed within the framework of the research project "Szenarien für den Ausbau der erneuerbaren Energien aus Naturschutzsicht". The German Federal Ministry for Nature Conservation has funded the research project (funding code 351582 2900).

\section{Availability of data and materials}

The nationwide data used for nature conservation assessment have been collected in the context of the research project "Szenarien für den Ausbau der erneuerbaren Energien aus Naturschutzsicht" and made available by the Federal Ministry for Nature Conservation, among others. Unfortunately, it is not publicly available. A more comprehensive list of the data and map materials will follow with the final report of the research project mentioned above, which will be published shortly.

\section{Ethics approval and consent to participate}

Not applicable.

\section{Consent for publication}

Not applicable.

\section{Competing interests}

The authors strive for neutral and open-ended research. The methods developed here can be used as a tool in policy consulting. It is not possible and not in the authors' intention to use the methodology to evaluate individual locations in a way that would constitute a conflict of interest. At the present stage of research, the authors declare that they have no competing interests, particularly because the focus is on a single energy source (onshore wind energy).

\section{Author details}

${ }^{1}$ Fraunhofer IEE, Königstor 59, 34119 Kassel, Germany. ${ }^{2}$ Bosch \& Partner $\mathrm{GmbH}$, Kantstraße 63a, 10627 Berlin, Germany.

\section{Received: 21 February 2019 Accepted: 27 November 2019} Published online: 18 December 2019

\section{References}

1. Federal Agency for Nature Conservation (eds) (2019) Erneuerbare Energien Report. Bonn - Bad Godesberg Februar 2019, 1. Auflage.

2. Agora Energiewende (eds) (2019) Die Energiewende im Stromsektor: Stand der Dinge 2018. Rückblick auf die wesentlichen Entwicklungen sowie Ausblick auf 2019.

3. Federal Agency for Nature Conservation (eds) (2011) Windkraft über Wald Positionspapier des Bundesamtes für Naturschutz, Bonn, Juli 2011.
4. Federal Agency for Nature Conservation (eds) (2017) Position des BfN zur Nutzung der Windenergie an Land. https://www.bfn.de/themen/ erneuerbare-energien/windenergie-onshore/position-windenergie-onshore. html Accessed 09 Feb 2019.

5. Federal Ministry for Economic Affairs and Energy (eds) (2018) Erneuerbare Energien in Zahlen - Nationale und internationale Entwicklung im Jahr 2017, Berlin, September 2018.

6. 50 Hertz Transmission $\mathrm{GmbH}$, Amprion GmbH, TenneT TSO GmbH \& TransnetBW GmbH (2017) Netzentwicklungsplan Strom 2030, Version 2017. Zweiter Entwurf der Übertragungs-netzbetreiber.

7. Demuth B, Heiland S, Luick R, Dimitri V, Ammermann K, Wiersbinski N (eds) (2016) Die Energiewende im Spannungsfeld energiepolitischer Ziele, gesellschaftlicher Akzeptanz und naturschutzfachlicher Anforderungen. BfNSkripten 433.

8. Shifeng W, Sicong W (2015) Impacts of wind energy on environment: a review. Renewable and Sustainable Energy Reviews 49(September 2015): 437-443

9. Tosh DG, Montgomery, WI \& Reid, N (2014). A review of the impacts of wind energy developments on biodiversity. Report prepared by the Natural Heritage Research Partnership (NHRP) between Quercus, Queen's University Belfast and the Northern Ireland Environment Agency (NIEA) for the Research and Development Series No. 14/02.

10. Frantál B, Bevk T, Van Veelen B, Hărmănescu M, Benediktsson K (2017) The importance of on-site evaluation for placing renewable energy in the landscape: a case study of the Búrfell wind farm (Iceland). Moravian Geographical Reports, 2017, 25(4): 234-247.

11. WWF Deutschland (eds) (2018) ZUKUNFT STROMSYSTEM II Regionalisierung der erneuerbaren Stromerzeugung. Vom Ziel her denken.

12. Agora Energiewende (eds) (2013) Kostenoptimaler Ausbau der Erneuerbaren Energien in Deutschland.

13. Federal Agency for Nature Conservation (eds) (2018) Naturverträgliche Energieversorgung aus 100 \% erneuerbaren Energien 2050. BfN-Skripten 501.

14. Grau L, Jung C, Schindler D (2017) On the annual cycle of meteorological and geographical potential of wind energy: a case study from southwest Germany. Sustainability 2017(9):1169

15. Jäger T, McKenna R, Fichtner W (2016) The feasible onshore wind energy potential in Baden-Württemberg: a bottom-up methodology considering socio-economic constraints. Renewable Energy, Volume 96, Part A, October 2016, Pages 662-675.

16. Drechsler M, Ohl C, Meyerhoff J, Eichhorn M, Monsees J (2011) Combining spatial modeling and choice experiments for the optimal spatial allocation of wind turbines. Energy Policy, Volume 39, Issue 6 , June 2011, Pages 3845-3854.

17. Naegler T (2017) Conference Paper "Multikriterielle Bewertung von Energieszenarien unter Berücksichtigung von ökologischen Gesichtspunkten".

18. Cowell R (2010) Wind power, landscape and strategic, spatial planning - the construction of 'acceptable locations' in Wales. Land Use Policy, Volume 27, Issue 2, April 2010, Pages 222-232.

19. Stevens R J A M (2015) Dependence of optimal wind turbine spacing on wind farm length. Wind Energy, Volume19, Issue 4, April 2016, Pages 651-663.

20. Abdelsalam A M, El-Shorbagy M (2018) Optimization of wind turbines siting in a wind farm using genetic algorithm based local search. Renewable Energy, 20 February, pp. 748-755.

21. Serrano González J, Gonzalez Rodriquez A G, Castro Mora J \& Riquelme Santos J (2010) Optimization of wind farm turbines layout using an evolutive algorithm. Renewable Energy, pp. 1671-1681.

22. Naturschutzbund Deutschland (NABU) e.V. (2018) Hintergrund Windenergie. Text: Römer I, Lachmann L, Scholz S, Adler S, Böhnke-Henrichs A, Detloff K, Kolberg S, Lindemann C \& Reincke J, Bundesfachausschuss Energie und Klima. December 2018.

23. Peters W, Klinski S, Eisser S \& Schäfer B (2010) Naturschutzstandards Erneuerbarer Energien. Research project funded by the German Federal Ministry for Nature Conservation (funding code: 0325016).

24. Federal Agency for Nature Conservation (2016) Datensatz: Schutzgebiete (FFHGebiete Deutschlands; Naturschutzgebiete Deutschlands; Landschaftsschutzgebiete Deutschlands; Vogelschutzgebiete Deutschlands (SPA))

25. Federal Agency for Nature Conservation (2017) Datensatz: Schutzgebiete (Biosphärenreservate Deutschlands (UNESCO); Zonierung der Biosphärenreservate Deutschlands; Nationalparke Deutschlands; Naturparke Deutschlands). 
26. Naturschutzbund Deutschland (NABU) e.V. (2013) Datensatz: Important Bird Area (IBA) Birds Directive (2013) European Environmental Agency, unter https://bergenhusen.nabu.de/forschung/ibas/index.html

27. Federal Institute of Hydrology (BfG) (2010) Datensatz: Wasserschutzgebiete und Heilquellenschutzgebiete bundesweit.

28. Federal Institute of Hydrology (BfG) (2015) Datensatz: Wasserschutzgebiete und Heilquellenschutzgebiete bundesweit.

29. Federal Agency for Cartography and Geodesy (BKG) (2012) Datensatz: Digitales Basis Landschaftsmodell (AAA-Modellierung) Basis-DLM (AAA) (ATKIS-AAA-Basis-DLM).

30. Dachverband Deutscher Avifaunisten (DDA) e.V. (2016) Zuweisung von GOR/NE Landnutzungsklassen zum Brutzeitlebensraum (Brut- und Nahrungshabitat während der Brutzeit) einer Auswahl windkraftsensitiver Vogelarten, Stand: November 2016.

31. Federal Agency for Nature Conservation (2003) Datensatz: Historisch Waldstandorte Deutschlands, erstellt unter Verwendung von ๑ GeoBasis-DE / BKG (2009).

32. Federal Agency for Nature Conservation (2009) Datensatz: Flussauen / Auensegmente und Bilanzierung, erstellt unter Verwendung von $\odot$ GeoBasis-DE / BKG (2009).

33. Sackman H (1974) Delphi Assessment: Expert Opinion, Forecasting an Group Process.

34. Arbach S, Horst D, Knorr K, Hegerkamp M, Scheibe M, Härtel P, Schwinn R, Spiekermann R \& Bofinger $S$ (all Fraunhofer IWES), Rendel T (IEH Hannover) (2013) Virtuelles Stromversorgungssystem - Komplettsimulation zukünftiger Stromversorgungssysteme. Abschlussbericht. Förderkennzeichen 0325172A und 0325172B. Kassel.

35. Baldauf M, Förstner J, Klink S, Reinhardt T, Schraff C, Seifert A \& Stephan K (2016) Kurze Beschreibung des Lokal-Modells Kurzestfrist COSMO-DE (LMK) und seiner Datenbanken auf dem Datenserver des DWD. Hg. v. Deutscher Wetterdienst (DWD)

36. Härtel $P$, Mende $D$, Stappel $M$, Puchta $M$, Horst $D$, Löwer $L$ \& Bofinger $S$ (all Fraunhofer IEE), Hahn P, Bley A (University Kassel), Leveringhaus T, Hofmann L (University Hannover) (2018): North Seas Offshore Network: Machbarkeit und Implikationen verschiedener Offshore-Netzkonzepte in der Nordseeregion. Schlussbericht des Verbundprojekts. Kassel, June 2018.

37. Piorr D (2013) Ausweisung von Konzentrationszonen für Windenergieanlagen und Immissionsschutz. Draft 30 Aug 2013.

38. Seifert $H$, Kröning J, Hahm T, Rohden R, Freudenreich $K$, Jöckel $S$ \& Birkemeyer J (2003) Abstandsregelung in Windparks, DEWI Magazin Nr. 22.

39. WindGuard (2019) Windenergiestatistik: Windenergie-Ausbau in Deutschland. Website with links to annual studies.

40. Eichhorn M, Masurowski F, Becker R, Thrän D (2019) Wind energy expansion scenarios - a spatial sustainability assessment. Energy Volume 180:367-375

41. Eichhorn M, Tafarte $P$ \& Thrän D (2017) Towards energy landscapes "Pathfinder for sustainable wind power locations". Energy Volume 134 pages 611-621.Federal Agency for Cartography and Geodesy (BKG) (2012) Datensatz: CORINE Land Cover 10 ha.

42. Braun M, Krybus I, Becker H, Bolgaryn R, Dasenbrock J, Gauglitz P, Horst D, Pape C, Scheidler A \& Ulffers J (2018) Verteilnetzstudie Hessen 2024 -2034. Studie im Auftrag des Hessischen Ministeriums für Wirtschaft, Energie, Verkehr und Landentwicklung. https:/www.energieland.hessen.de/mm/ Verteilnetzstudie_Hessen_2024_bis_2034.pdf. Accessed 01 Feb 2019

43. Jetter F, Schmid T \& Gallet M (2016) Konzept und Daten zur Regionalisierung von erneuerbaren Energien. Grundlage für die Abbildung regionalisierter Szenarien im Netzentwicklungsplan Strom 2030. Forschungsstelle für Energiewirtschaft e.V. "https://www.ffe.de/download/ article/616/20160518_Begleitdokument_regionalisierung_erneuerbarer_ energien.pdf. Accessed 01 Feb 2019

44. Sánchez-Lozano J M, García-Cascales, M S \& Lamata M T, (2016) GIS-based onshore wind farm site selection using Fuzzy Multi-Criteria Decision Making methods. Evaluating the case of Southeastern Spain. Applied Energy, 22 March, pp. 86 - 102.

45. Aktasa A, Kabak M (2016) A model proposal for locating wind turbines. Procedia Computer Science 102(2016):426-433

\section{Publisher's Note}

Springer Nature remains neutral with regard to jurisdictional claims in published maps and institutional affiliations.

Ready to submit your research? Choose BMC and benefit from:

- fast, convenient online submission

- thorough peer review by experienced researchers in your field

- rapid publication on acceptance

- support for research data, including large and complex data types

- gold Open Access which fosters wider collaboration and increased citations

- maximum visibility for your research: over $100 \mathrm{M}$ website views per year

At BMC, research is always in progress.

Learn more biomedcentral.com/submissions 